Joëlle Jourdan, Annabelle Walz, Hugues Matile, Alexander Schmidt, Jianbo Wu, Xiaofang Wang, Yuxiang Dong, Jonathan L. Vennerstrom, Remo S. Schmidt, Sergio Wittlin, Pascal Mäser

\title{
Stochastic protein alkylation by antimalarial peroxides
}

\section{Supplementary Material}

[4 figures and 3 tables; 8 pages plus 3 additional Excel files]

$\begin{array}{lll}\text { Supplementary Methods: } & \text { Chemical syntheses }\end{array}$

Supplementary Figure S1: Optimization of assay parameters S5

Supplementary Figure S2: $\quad$ Optimization of washing procedure I $\quad$ S6

Supplementary Figure S3: $\quad$ Optimization of washing procedure II $\quad$ S7

Supplementary Figure S4: $\quad$ Proteomics with synchronized cultures $\quad$ S8

Supplementary Table S1: $\quad$ List of alkylated P. falciparum proteins $\quad$ separate Excel file

Supplementary Table S2: Overlap with published datasets separate Excel file

Supplementary Table S3: $\quad$ Proteomics with synchronized cultures separate Excel file 


\section{Chemical syntheses}

As shown in Scheme 1, ozonide alkyne click chemistry probes OZ726 and OZ727 were prepared in one or two steps from keto ozonide 3. Amino ozonide 4 and OZ727 were isolated as their mesylate salts; structures depicted are the free base forms. Griesbaum coozonolysis (Griesbaum et al., 1997) of dione 1 and oxime ether $\mathbf{2}$ afforded 3 in 65\% yield. Reductive amination reactions of 3 afforded 4 and OZ726 in yields of 75 and 76\%, respectively. Acylation of 4 afforded OZ727 in 59\% yield. The non-peroxide control carbaOZ727 was prepared in a three-step sequence starting with monoketalization of 1 with diol 5 to form keto dioxolane 6 in 86\% yield (Scheme 2). This was followed by reductive amination and acylation to afford carbaOZ277 in a combined yield of $21 \%$.

\section{Scheme 1a}

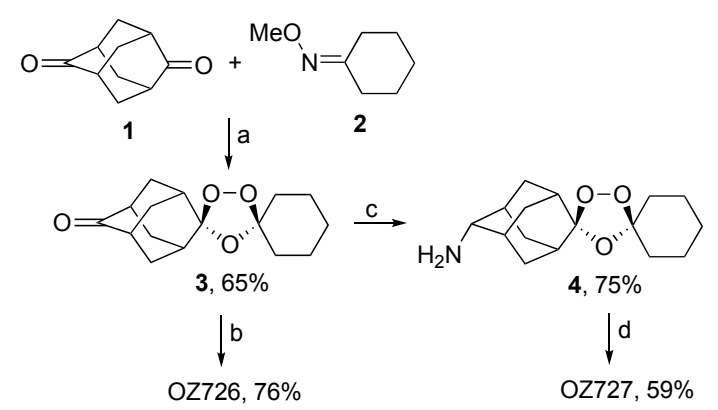

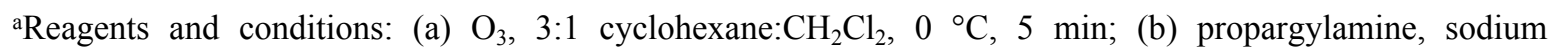
triacetoxyborohydride, $\mathrm{AcOH}, 1: 1 \mathrm{CH}_{2} \mathrm{Cl}_{2}: \mathrm{ClCH}_{2} \mathrm{Cl}_{2} \mathrm{Cl}$, rt, 14 h, then $\mathrm{MsOH}$, EtOAc, rt, $0.5 \mathrm{~h}$; (c) $\mathrm{NaCNBH}_{3}$, $\mathrm{NH}_{4} \mathrm{OAc}, \mathrm{AcOH}, \mathrm{MeOH}, \mathrm{rt}, 14 \mathrm{~h}$, then $\mathrm{MsOH}, \mathrm{EtOAc}, \mathrm{rt}, 0.5 \mathrm{~h}$; (d) 4-pentynoic acid, HOBt, EDCI, $\mathrm{NEt}_{3}$, DMF, rt, $24 \mathrm{~h}$.

\section{Scheme 2a}

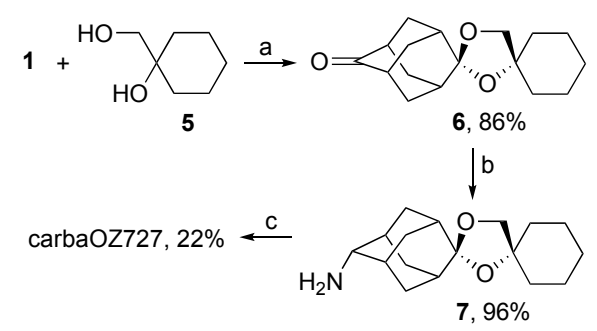

aReagents and conditions: (a) p-TSA, $\mathrm{CH}_{2} \mathrm{Cl}_{2}$, rt, 20 h; (b) $\mathrm{NaCNBH}_{3}, \mathrm{NH}_{4} \mathrm{OAc}, \mathrm{AcOH}, \mathrm{MeOH}, \mathrm{rt}, 13$ h; (c) 4pentynoic acid, HOBt, EDCI, DMF, rt, $21 \mathrm{~h}$. 
General. Melting points are uncorrected. 1D ${ }^{1} \mathrm{H}$ and ${ }^{13} \mathrm{C}$ NMR spectra were recorded on a $500 \mathrm{MHz}$ spectrometer using $\mathrm{CDCl}_{3}$ or DMSO- $d_{6}$ as solvents. All chemical shifts are reported in parts per million (ppm) and are relative to internal $\left(\mathrm{CH}_{3}\right)_{4} \mathrm{Si}(0 \mathrm{ppm})$ for ${ }^{1} \mathrm{H}$ and $\mathrm{CDCl}_{3}(77.2 \mathrm{ppm})$ or DMSO$d_{6}(39.5 \mathrm{ppm})$ for ${ }^{13} \mathrm{C}$ NMR. Silica gel (sg) particle size $32-63 \mu \mathrm{m}$ was used for all flash column chromatography. Reported reaction temperatures are those of the oil bath.

cis-6-Oxoadamantane-2-spiro-3'-1',2',4'-trioxaspiro[4.5]decane (3). A solution of adamantane2,6-dione (1) $(3.20 \mathrm{~g}, 19.5 \mathrm{mmol})$ and $O$-methyl cyclohexanone oxime (2) $(1.27 \mathrm{~g}, 10.0 \mathrm{mmol})$ in cyclohexane $(120 \mathrm{~mL})$ and $\mathrm{CH}_{2} \mathrm{Cl}_{2}(40 \mathrm{~mL})$ was treated with ozone according to the method of Dong et al (Dong et al., 2005). After solvent removal, the crude product was purified by sg flash chromatography to afford $3(1.32 \mathrm{~g}, 65 \%)$ as colorless solid. mp $70-71{ }^{\circ} \mathrm{C} ;{ }^{1} \mathrm{H}$ NMR $\left(\mathrm{CDCl}_{3}\right) \delta 1.35-$ $1.51(\mathrm{~m}, 2 \mathrm{H}), 1.56-1.71(\mathrm{~m}, 4 \mathrm{H}), 1.71-1.82(\mathrm{~m}, 4 \mathrm{H}), 1.92(\mathrm{~d}, J=13 \mathrm{~Hz}, 2 \mathrm{H}), 1.98(\mathrm{~d}, J=13 \mathrm{~Hz}, 2 \mathrm{H})$, $2.12(\mathrm{~s}, 2 \mathrm{H}), 2.25(\mathrm{~d}, J=13 \mathrm{~Hz}, 2 \mathrm{H}), 2.36(\mathrm{~d}, J=13 \mathrm{~Hz}, 2 \mathrm{H}), 2.44-2.52(\mathrm{~m}, 2 \mathrm{H}) ;{ }^{13} \mathrm{C} \mathrm{NMR}\left(\mathrm{CDCl}_{3}\right)$ $\delta$ 23.82, 24.88, 34.65, 35.67, 35.71, 35.94, 44.73, 45.16, 108.93, 109.79, 216.04. Anal. Calcd for $\mathrm{C}_{16} \mathrm{H}_{22} \mathrm{O}_{4}$ : C, 69.04; H, 7.97. Found: C, 69.02; H, 7.75.

cis-Dispiro[adamantane-2,3'-[1,2,4]trioxolane-5',1"-cyclohexan]-6-amine mesylate (4). To a solution of $3(0.15 \mathrm{~g}, 0.54 \mathrm{mmol})$ in $\mathrm{MeOH}(10 \mathrm{~mL})$ were added ammonium acetate $(0.5 \mathrm{~g}, 6.49$ $\mathrm{mmol})$ and acetic acid $(1.0 \mathrm{~mL})$. The resulting mixture was stirred at $\mathrm{rt}$ for $2 \mathrm{~h}$ before sodium cyanoborohydride $(0.10 \mathrm{~g}, 1.60 \mathrm{mmol})$ was added. The reaction mixture was stirred overnight and then quenched with $1 \mathrm{M} \mathrm{NaOH}(2 \mathrm{~mL})$. After removal of solvents in vacuo, the residue was dissolved in EtOAc $(20 \mathrm{~mL})$, and washed with water $(10 \mathrm{~mL})$ and brine $(10 \mathrm{~mL})$. The organic layer was dried over $\mathrm{MgSO}_{4}$, filtered and concentrated. The residue was dissolved in EtOAc $(5 \mathrm{~mL})$ and then a solution of methanesulfonic acid $(0.05 \mathrm{~g})$ in ethyl acetate $(20 \mathrm{~mL})$ was added. The precipitate was collected by filtration to afford $4(0.15 \mathrm{~g}, 75 \%)$ as a colorless solid. mp $172-173{ }^{\circ} \mathrm{C} .{ }^{1} \mathrm{H}$ NMR $\left(\mathrm{DMSO}-d_{6}\right) \delta 1.30-2.08(\mathrm{~m}, 22 \mathrm{H}), 2.50(\mathrm{~s}, 3 \mathrm{H}), 3.33(\mathrm{~s}, 1 \mathrm{H}), 7.41$ (brs, 3H); ${ }^{13} \mathrm{C}$ NMR (DMSO- $\left.d_{6}\right) \delta$ $23.65,24.38,27.12,29.15,29.55,33.37,33.49,34.29,34.68,34.97,53.66,109.02,109.84$.

\section{cis- $N$-(prop-2-yn-1-yl)dispiro[adamantane-2,3'-[1,2,4]trioxolane-5',1"'-cyclohexan]-6-amine} mesylate (OZ726). To a solution of $3(0.22 \mathrm{~g}, 0.79 \mathrm{mmol})$ in $\mathrm{CH}_{2} \mathrm{Cl}_{2}(5 \mathrm{~mL})$ and $\mathrm{ClCH}_{2} \mathrm{CH}_{2} \mathrm{Cl}(5$ $\mathrm{mL})$ were added propargylamine $(0.20 \mathrm{~g}, 3.64 \mathrm{mmol})$ and acetic acid $(1 \mathrm{~mL})$. The resulting mixture was stirred at $\mathrm{rt}$ for $2 \mathrm{~h}$ before sodium triacetoxyborohydride $(0.22 \mathrm{~g}, 1.03 \mathrm{mmol})$ was added. The reaction mixture was stirred overnight and then quenched with $1 \mathrm{M} \mathrm{NaOH}(2 \mathrm{~mL})$. The organic layer 
was separated and washed with water $(10 \mathrm{~mL})$, brine $(10 \mathrm{~mL})$, dried over $\mathrm{MgSO}_{4}$, and concentrated. The residue was dissolved in EtOAc $(5 \mathrm{~mL})$ and then a solution of methanesulfonic acid $(0.06 \mathrm{~g})$ in ethyl acetate $(20 \mathrm{~mL})$ was added. The precipitate was collected by filtration to afford $\mathbf{O Z 7 2 6}(0.25 \mathrm{~g}$, $76 \%)$ as a colorless solid. mp $167-168^{\circ} \mathrm{C} .{ }^{1} \mathrm{H}$ NMR $\left(\mathrm{CDCl}_{3}\right) \delta 1.32-1.50(\mathrm{~m}, 2 \mathrm{H}), 1.54-2.30(\mathrm{~m}$, $20 \mathrm{H}), 2.51(\mathrm{~s}, 1 \mathrm{H}), 2.78(\mathrm{~s}, 3 \mathrm{H}), 3.54(\mathrm{~s}, 1 \mathrm{H}), 3.96-4.12(\mathrm{~m}, 2 \mathrm{H}), 9.05$ (brs, $2 \mathrm{H}) ;{ }^{13} \mathrm{C} \mathrm{NMR}\left(\mathrm{CDCl}_{3}\right) \delta$ 23.78, 24.88, 27.19, 27.37, 27.47, 27.74, 33.89, 34.02, 34.47, 34.63, 34.99, 35.13, 39.34, 59.63, 73.65, 109.56. Anal. Calcd for $\mathrm{C}_{20} \mathrm{H}_{31} \mathrm{NO}_{6} \mathrm{~S}$ : C, 58.09; H, 7.56; N, 3.39. Found: C, 58.07; H, 7.52; N, 3.30.

\section{cis- $\mathrm{N}$-dispiro[adamantane-2,3'-[1,2,4]trioxolane-5',1"'-cyclohexan]-6-yl)pent-4-ynamide}

(OZ727). A mixture of 4-pentynoic acid (0.10 g, $1.0 \mathrm{mmol})$, HOBt (0.14 g, $1.0 \mathrm{mmol})$, EDCI (0.20 g, $1.0 \mathrm{mmol})$ in DMF $(5 \mathrm{~mL})$ was stirred at $\mathrm{rt}$ for $2 \mathrm{~h}$. Then $4(0.20 \mathrm{~g}, 0.69 \mathrm{mmol})$ and $\mathrm{NEt}_{3}(1 \mathrm{~mL})$ were added and the resulting mixture was stirred at $\mathrm{rt}$ for $24 \mathrm{~h}$. Under ice cooling, the reaction was quenched with water $(20 \mathrm{~mL})$. The precipitate was collected by filtration, washed with cold water, and dried in vacuo at $40{ }^{\circ} \mathrm{C}$ to afford $\mathrm{OZ727}(0.15 \mathrm{~g}, 59 \%)$ as colorless solid. mp $151-152^{\circ} \mathrm{C} .{ }^{1} \mathrm{H}$ NMR $\left(\mathrm{CDCl}_{3}\right) \delta 1.32-1.48(\mathrm{~m}, 2 \mathrm{H}), 1.54-1.88(\mathrm{~m}, 14 \mathrm{H}), 1.90-1.96(\mathrm{~m}, 3 \mathrm{H}), 1.96-2.05(\mathrm{~m}, 3 \mathrm{H})$, $2.08-2.14(\mathrm{~m}, 1 \mathrm{H}), 2.43(\mathrm{t}, J=7.0 \mathrm{~Hz}, 2 \mathrm{H}), 2.54\left(\mathrm{td}, J_{1}=7.0 \mathrm{~Hz}, J_{2}=2.5 \mathrm{~Hz}, 2 \mathrm{H}\right), 4.00(\mathrm{~d}, J=8.0$ $\mathrm{Hz}, 1 \mathrm{H}), 6.01(\mathrm{~d}, 1 \mathrm{H}) ;{ }^{13} \mathrm{C} \mathrm{NMR}\left(\mathrm{CDCl}_{3}\right) \delta 15.12,23.80,23.86,24.92,29.17,30.20,30.59,33.94$, $34.05,34.70,34.73,35.29,35.46,35.64,52.48,69.63,83.19,109.29,110.41,170.21$. Anal. Calcd for $\mathrm{C}_{21} \mathrm{H}_{29} \mathrm{NO}_{4}$ : C, 70.17; H, 8.13; N, 3.90. Found: C, 70.39; H, 8.15; N, 4.07. HRMS (ESI-TOF) m/z: $[\mathrm{M}]^{+}$Calcd for $\mathrm{C}_{21} \mathrm{H}_{29} \mathrm{NO}_{4}$ 359.2097; Found 359.2105.

\section{$N$-dispiro[adamantane-2,2'-[1,3]dioxolane-4',1'-cyclohexan]-6-yl)pent-4-ynamide}

(carbaOZ727). Step 1. A mixture of 1-(hydroxymethyl)cyclohexan-1-ol (5) (0.31 g, 2.38 mmol), adamantane-2,6-dione (1) (0.78 g, $4.76 \mathrm{mmol})$ and $p$-toluenesulfonic acid monohydrate (0.09 $\mathrm{mg}$, $0.47 \mathrm{mmol})$ in $\mathrm{CH}_{2} \mathrm{Cl}_{2}(30 \mathrm{~mL})$ was stirred at $\mathrm{rt}$ for $20 \mathrm{~h}$. The reaction mixture was then washed with saturated $\mathrm{NaHCO}_{3}(10 \mathrm{~mL})$, water $(10 \mathrm{~mL})$ and brine $(10 \mathrm{~mL})$, dried over $\mathrm{MgSO}_{4}$, filtered and concentrated. The residue was purified by sg chromatography eluting with $\mathrm{CH}_{2} \mathrm{Cl}_{2}$ to afford 6oxoadamantane-2-spiro-5'-1',3'-dioxaspiro[4.5]decane (6) $(0.57 \mathrm{~g}, 86 \%)$ as white solid. $\mathrm{mp} 63-64{ }^{\circ} \mathrm{C}$; ${ }^{1} \mathrm{H}$ NMR $\left(\mathrm{CDCl}_{3}\right) \delta 1.46-1.36(\mathrm{~m}, 4 \mathrm{H}), 1.77-1.65(\mathrm{~m}, 5 \mathrm{H}), 1.91-1.86(\mathrm{~m}, 5 \mathrm{H}), 2.32(\mathrm{~d}, J=10 \mathrm{~Hz}$, $2 \mathrm{H}), 2.40(\mathrm{~d}, J=15 \mathrm{~Hz}, 2 \mathrm{H}), 2.46(\mathrm{~d}, J=15 \mathrm{~Hz}, 2 \mathrm{H}), 3.80(\mathrm{~s}, 2 \mathrm{H}) ;{ }^{13} \mathrm{C} \mathrm{NMR}\left(\mathrm{CDCl}_{3}\right) \delta 23.64,25.38$, $35.82,35.94,36.87,37.59,45.13,45.47,73.79,80.97,109.16,217.27$. Step 2. A mixture of $6(0.800$ g, $2.89 \mathrm{mmol}), \mathrm{NH}_{4} \mathrm{OAc}(2.68 \mathrm{~g}, 34.68 \mathrm{mmol})$ and $\mathrm{HOAc}(0.10 \mathrm{~mL})$ in methanol $(30 \mathrm{~mL})$ was stirred at $\mathrm{rt}$ for $30 \mathrm{~min}$ before the addition of $\mathrm{NaCNBH}_{3}(455 \mathrm{mg}, 11.56 \mathrm{mmol}$. The resulting mixture was 
stirred for $12 \mathrm{~h}$ before quenching with $1 \mathrm{M} \mathrm{NaOH}(10 \mathrm{~mL})$. After solvent removal in vacuo, the residue was extracted with EtOAc $(50 \mathrm{~mL})$ and washed with $1 \mathrm{M} \mathrm{NaOH}(10 \mathrm{~mL})$ and brine $(10 \mathrm{~mL})$. The organic layer was dried over $\mathrm{MgSO}_{4}$, filtered and concentrated to afford 6-aminoadamantane-2spiro-5'-1',3'-dioxaspiro[4.5]decane (7) as a white solid (0.796 g, 96\%). ${ }^{1} \mathrm{H}$ NMR $\left(\mathrm{CDCl}_{3}\right) \delta 2.16-$ $1.39(\mathrm{~m}, 22 \mathrm{H}), 2.97$ (s, 1H), 3.75 (s, 2H). Step 3. To a mixture of 4-pentynoic acid ( $0.19 \mathrm{~g}, 2.0 \mathrm{mmol})$ and HOBt $(0.27 \mathrm{~g}, 2.0 \mathrm{mmol})$ in DMF $(7 \mathrm{~mL})$ was added EDCI $(0.52 \mathrm{~g}, 2.7 \mathrm{mmol})$ and the resulting mixture was stirred at $\mathrm{rt}$ for $1 \mathrm{~h}$. Then $7(0.50 \mathrm{~g}, 1.8 \mathrm{mmol})$ in DMF $(3 \mathrm{~mL})$ was added to the reaction mixture dropwise and the mixture was stirred at $\mathrm{rt}$ for $20 \mathrm{~h}$. The reaction mixture was diluted with ethyl acetate $(40 \mathrm{~mL})$ and washed with brine $(3 \times 20 \mathrm{~mL})$, dried over $\mathrm{MgSO}_{4}$, filtered and concentrated. The residue was purified by sg chromatography (10:1 hexane:ethyl acetate) to afford $\operatorname{carbaOZ727}(0.14 \mathrm{~g}, 22 \%)$ as a colorless oil. ${ }^{1} \mathrm{H}$ NMR $\left(\mathrm{CDCl}_{3}\right) \delta 1.98-1.37(\mathrm{~m}, 20 \mathrm{H}), 2.09-2.05(\mathrm{~m}$, $2 \mathrm{H}), 2.15\left(\mathrm{dd}, J_{1}=3 \mathrm{~Hz}, J_{2}=13.0 \mathrm{~Hz}, 2 \mathrm{H}\right), 2.46(\mathrm{t}, J=7.0 \mathrm{~Hz}, 2 \mathrm{H}), 2.58\left(\mathrm{td}, J_{1}=1.5 \mathrm{~Hz}, J_{2}=7.0 \mathrm{~Hz}\right.$, $2 \mathrm{H}), 3.74(\mathrm{~s}, 2 \mathrm{H}), 4.01(\mathrm{~s}, 1 \mathrm{H}), 6.06(\mathrm{~d}, J=7 \mathrm{~Hz}, 1 \mathrm{H}) ;{ }^{13} \mathrm{C} \mathrm{NMR}\left(\mathrm{CDCl}_{3}\right) \delta 15.14,23.71,23.73,25.42$, 29.22, 29.27, 30.48, 30.81, 34.01, 34.04, 35.70, 36.97, 37.00, 37.06, 37.38, 52.83, 69.57, 73.46, 80.55, 83.24, 110.68, 170.13. HRMS (ESI-TOF) m/z: [M] ${ }^{+}$Calcd for $\mathrm{C}_{22} \mathrm{H}_{31} \mathrm{NO}_{3}$ 357.2304; Found 357.2319.

Griesbaum K, Liu X, Kassiaris A, Scherer M. Ozonolyses of $O$-alkylated ketoximes in the presence of carbonyl groups: A facile access to ozonides. Libigs Ann./Recueil 1997, 1381-1390.

Dong, Y.; Chollet, J.; Matile, H.; Charman, S. A.; Chiu, F. C. K.; Charman, W. N.; Scorneaux, B.; Urwyler, H.; Santo Tomas J.; Scheurer, C.; Snyder, C.; Dorn, A.; Wang, X.; Karle, J. M.; Tang, Y.; Wittlin, S.; Brun, R.; Vennerstrom, J. L. Spiro and dispiro-1,2,4-trioxolanes as antimalarial peroxides: Charting a workable SAR using simple prototypes. J. Med. Chem. 2005, 48, 4953-4961. 
Figure S1. Optimization of assay parameters as determined by Western blot. A) Different incubation times of $P$. falciparum cultures with $1000 \mathrm{ng} / \mathrm{ml}$ ozonide alkyne, exposure $10 \mathrm{~s}$; B) Different concentrations of ozonide alkyne at $4 \mathrm{~h}$ drug incubation, exposure $30 \mathrm{~s}$. Parasite cultures were lysed with RIPA-lysis buffer (see Material and Methods for details).

A

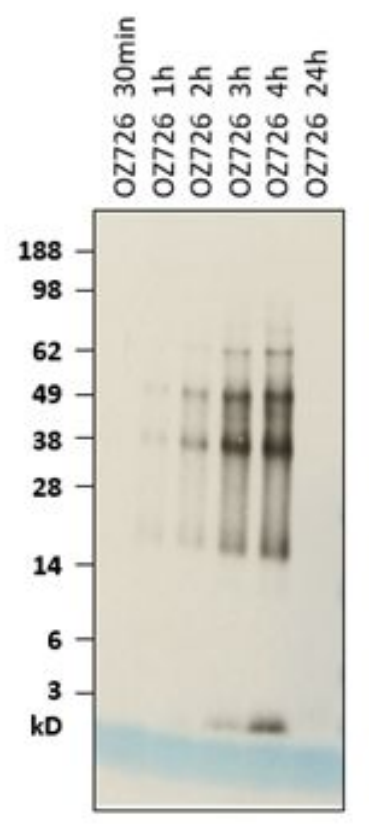

B
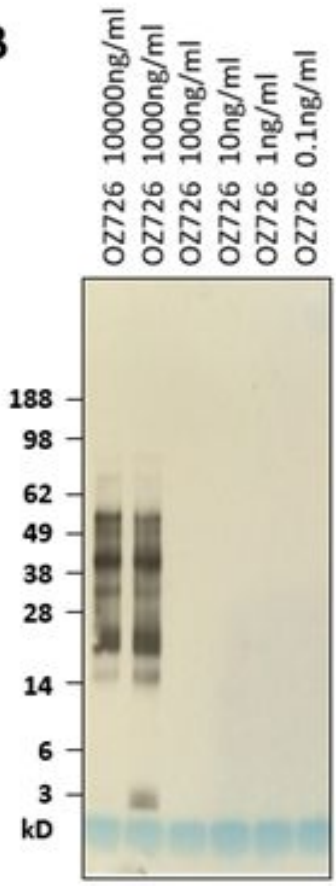
Figure S2. Washing of the neutravidin-coupled agarose beads after reaction with biotinylated peptides as determined by silver stain. P. falciparum cultures were incubated with $100 \mathrm{ng} / \mathrm{ml}$ AA2 or $0.1 \%$ DMSO for 4 h. Protein extracts were prepared with $1.2 \%$ SDS in PBS.

$\begin{array}{ll} & \text { Sample } \\ \mathbf{1} & \text { Beads only } \\ \mathbf{2} & \text { No treatment } \\ \mathbf{3} & \text { Artemisinin alkyne } 2 \\ 4 & \text { DMSO } \\ \mathbf{5} & \text { DMSO, beads preincubated with BSA } \\ \mathbf{6} & \text { DMSO, beads preincubated and incubated with BSA } \\ \mathbf{7} & \text { DMSO, beads preincubated with milk powder } \\ \mathbf{8} & \text { DMSO, beads preincubated and incubated with milk powder } \\ \mathbf{9} & \text { DMSO }\end{array}$

$5 x$ wash (too harsh):

- Denaturation solution ${ }^{*}$

- PBS

- $1 \%$ SDS

- $\mathrm{PBS}$

- $\mathrm{H}_{2} \mathrm{O}$

*Guanidine thiocyanate $4 \mathrm{M}$ Na-citrate $25 \mathrm{mM}$

Sarcosyl 0.5\%

Wash
$7 x$
$7 x$
$7 x$
$7 x$
$7 x$
$7 x$
$7 x$
$7 x$
$5 x$

\begin{tabular}{|l|}
\hline $7 x$ wash (final protocol: \\
- $1 \%$ SDS \\
- $1 \%$ SDS \\
- $0.1 \%$ SDS \\
- $6 \mathrm{M}$ Urea \\
- $\mathrm{PBS}$ \\
\hline $\mathrm{H}_{2} \mathrm{O}$ \\
\hline
\end{tabular}

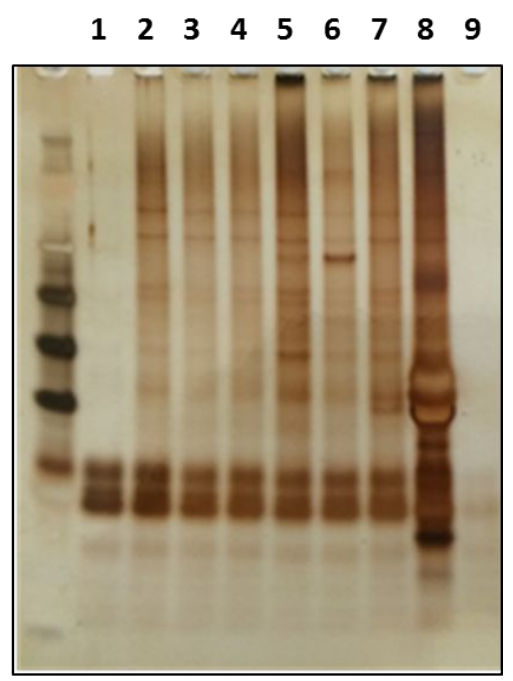


Figure S3. Washing of the neutravidin-coupled agarose beads after reaction with biotinylated peptides as determined by Western blot. $P$. falciparum cultures were treated with $100 \mathrm{ng} / \mathrm{ml} \mathrm{AA} 2$ or $0.1 \%$ DMSO for $4 \mathrm{~h}$ and extracts were prepared with $1.2 \%$ SDS in PBS. Exposure time $1 \mathrm{~min}$.
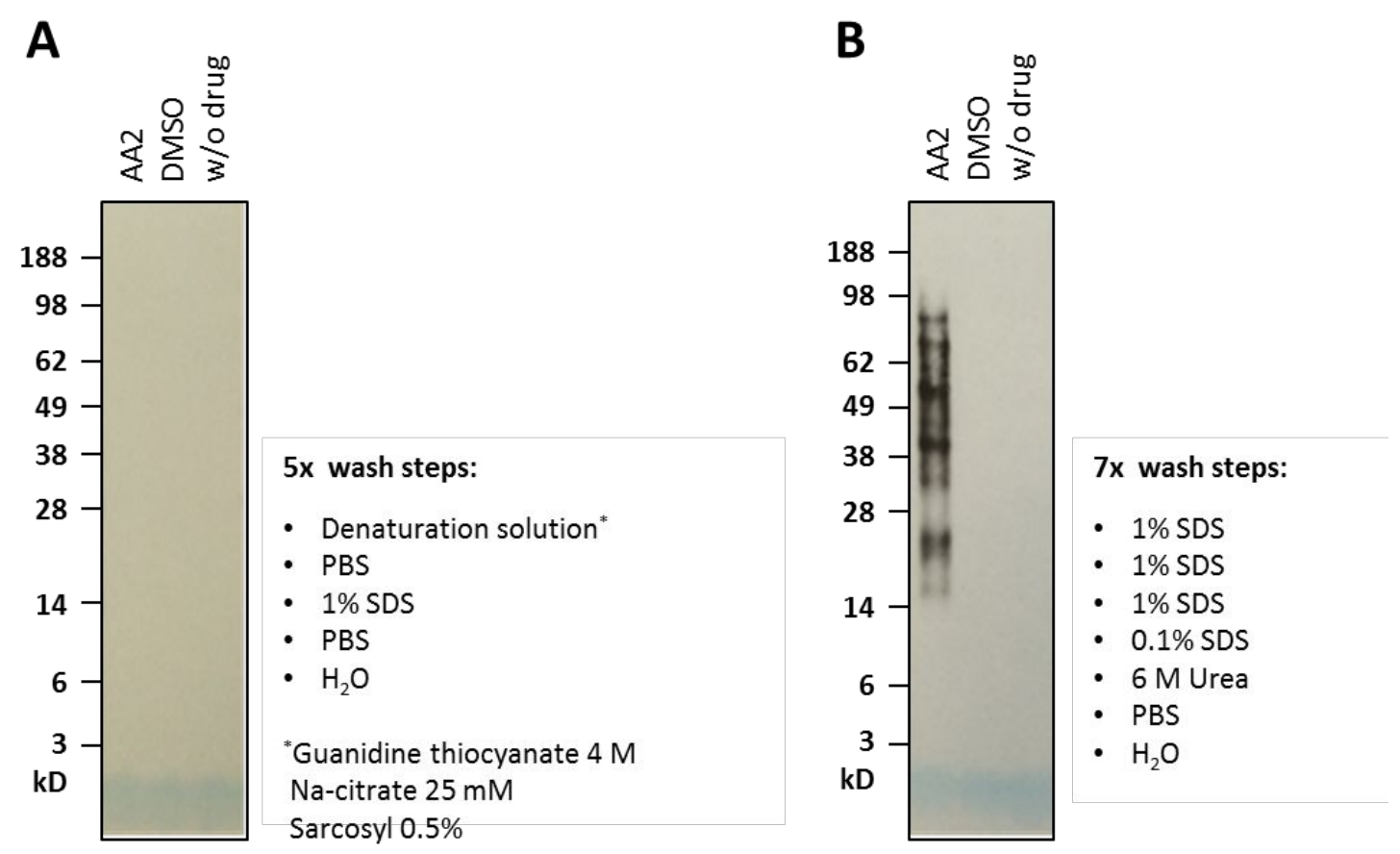
Figure S4. Chemical proteomics with artemisinin alkyne (AA2) on synchronized early ring stages of two P. falciparum strains, the K13 propeller mutant Cam3.1 ${ }^{\mathrm{R} 539 \mathrm{~T}}$ (red) and the engineered revertant Cam3.1 $1^{\mathrm{rev}}$ (blue). The numbers in the Venn diagram are proteins enriched at least 4-fold in the AA2-treated samples over the DMSO-treated control. The single protein present in all three replicates was a putative nucleoside triphosphate hydrolase (the ortholog of PF3D7_1352700) in P. falciparum Cam3.1 ${ }^{\mathrm{R} 539 \mathrm{~T}}$ and a putative zinc finger protein (the ortholog of PF3D7_1450400) in P. falciparum Cam3.1 ${ }^{\text {rev }}$. The NTP hydrolase was also present in two replicates of $P$. falciparum Cam3.1 ${ }^{\text {rev }}$. See Table $\mathrm{S} 3$ for all data and protein descriptions.

\section{Cam3.1 ${ }^{\text {R539T }}$}

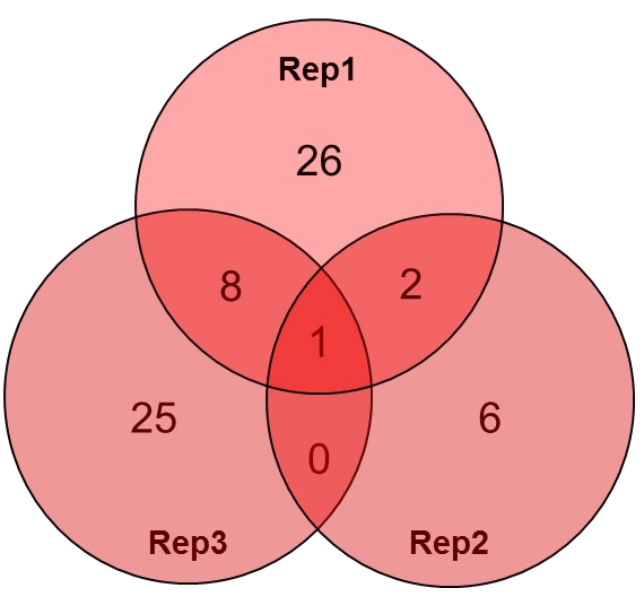

Cam3.1 ${ }^{\text {rev }}$

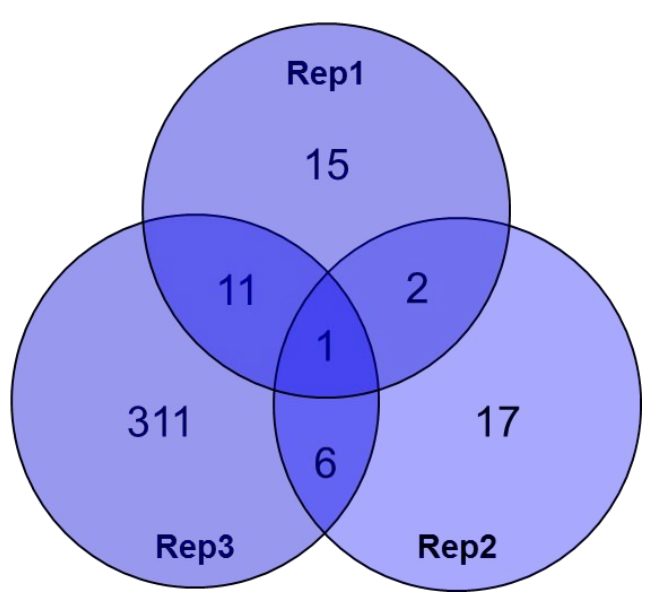

